\title{
Mediating the imaginary and the space of encounter in the Papuan Gulf
}

\author{
Dario Di Rosa
}

Writing about the 1935 Hides-O'Malley expedition in the Highlands of Papua New Guinea, the anthropologist Edward Schieffelin noted that Europeans "had a well-prepared category - "natives" - in which to place those people they met for the first time, a category of social subordination that served to dissipate their depth of otherness'. ${ }^{1}$ However, this category was often nuanced by Indigenous representations of neighbouring communities, producing significant effects in shaping Europeans' understanding of their encounters. Analysing the narrative produced by Joseph Beete Jukes, ${ }^{2}$ naturalist on Francis Price Blackwood's voyage of 1842-1846 on HMS Fly, I demonstrate the crucial role played by Torres Strait Islanders as mediators from afar of European encounters with Papuans along the coast of the Gulf of

\footnotetext{
$1 \quad$ Schieffelin and Crittenden 1991: 5.

2 Jukes 1847. As Beer (1996) shows, the viewing position of on-board scientists during geographical explorations was a particular one, led by their interests (see, from a different perspective, Fabian (2000) on the relevance of 'natural history' as episteme of accounts of explorations). This is a reminder of the high degree of social stratification within the 'European' micro-social community of the ship's crew, a social hierarchy that shaped the texts available to the historians. Although he does not treat the problem of social stratification as such, see Thomas 1994 for a well-argued discussion about the different projects that guided various colonial actors. See also Dening 1992 for vivid case of power relations in the micro-social cosmos of a ship.
} 
Papua in 1845. I focus predominantly on this particular text because it became a canonical reference for later explorations of the Gulf of Papua. I highlight two specific aspects of Torres Strait Islanders' mediation: a linguistic mediation which proved vital for the actual encounters; and the projection of certain stereotypes of Papuans which impinged on European imaginaries of 'the Natives'. ${ }^{3}$

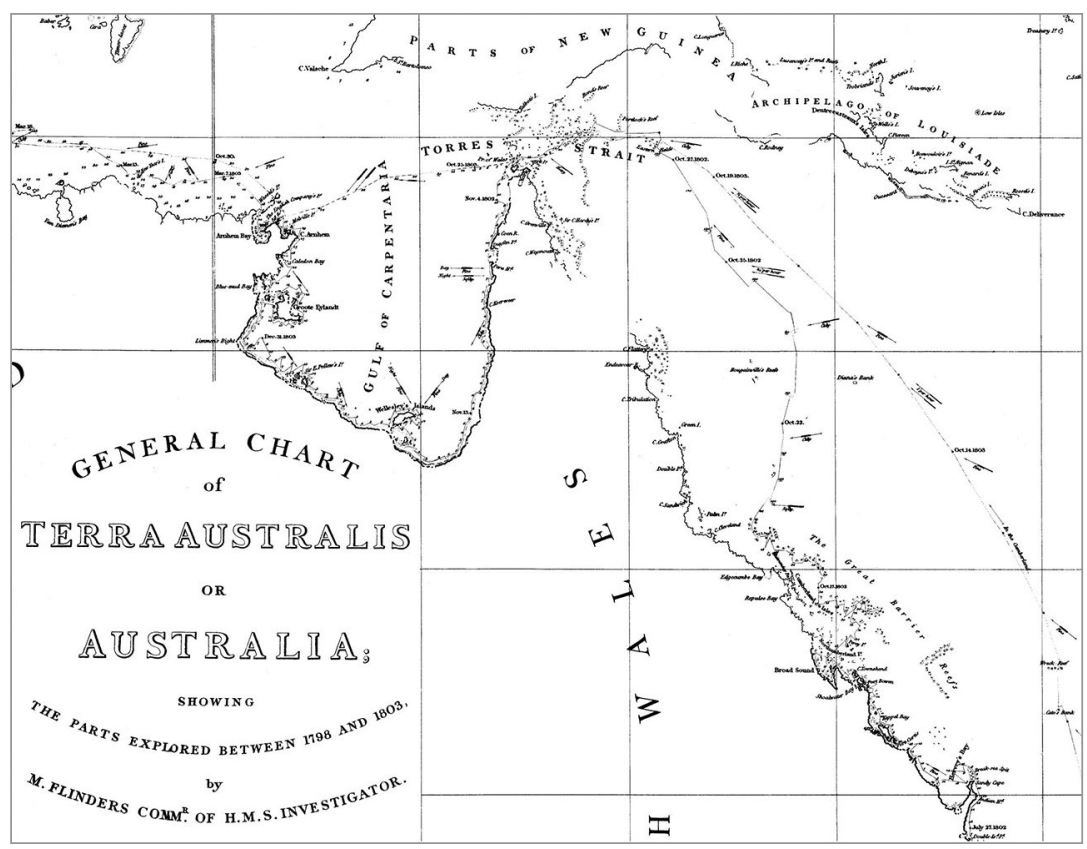

Figure 7.1: Detail of 'General Chart of Terra Australis or Australia: Showing Parts Explored Between 1798 and 1803 by M. Flinders Commr. of H.M.S. Investigator', 1822 [1814]. Source: National Library of Australia, MAP RM 1777.

By the 1840s, the seas of Torres Strait were regularly scoured by boats from Australia trying to reach Asian ports more quickly than was permitted by the longer and yet no safer passage north of New Guinea. ${ }^{4}$ However, those reef-strewn waters were dangerous and the

3 In using the term 'stereotype', I follow Michael Herzfeld's analysis of the performative construction of what he terms 'cultural intimacy' (2005 [1997]: especially chapter 9).

4 For a discussion of the available routes 'from the South Pacific to the Indian Ocean', see Jukes 1847, I: 305, note. In this paper, 'New Guinea' refers to the whole island now divided into the Indonesian provinces of Papua and West Papua and the nation of Papua New Guinea. I deal here with the western portion of what became the British Protectorate of New Guinea and, subsequently, the Australian Territory of Papua. 
cause of frequent shipwrecks, through which Torres Strait Islanders had already experienced sustained engagement with ships' crews. Lying between the Torres Strait and the northern passage through the Louisiade Archipelago at the eastern tip of New Guinea, the south coast of New Guinea was still poorly charted (Figure 7.1). ${ }^{5}$

The Fly sailed from England to the South Pacific in 1842. In August, the vessel reached Australia and spent over a year surveying its coasts. In 1845, Blackwood and his crew surveyed the Great Barrier Reef, Torres Strait, and the Gulf coast of New Guinea, a task that took more than a month (Figure 7.2). They spent several days at Darnley Island, known locally by the name of Erub. Interactions with Torres Strait Islanders were peaceful and oriented toward exchanges, particularly of food and 'curios' for iron tools. These exchanges produced a linguistic engagement and progressive acquisition of a vocabulary, mostly with the people of Erub. ${ }^{6}$ Here the English crew engaged particularly with two figures, named Mammoos and Seewai, who seemed to have been 'two of the most influential men of the island'. ${ }^{7}$ Preparing to leave for the south coast of New Guinea, and inquiring about their next destination, the English learned that Erubians called that place 'Dowdee' and regarded it as a vast land full of cuscus, a kind of possum. Information collected by Oswald W. Brierly, painter on board HMS Rattlesnake between 1848 and 1850, suggests that 'Dowdee' was part of a regional social geography created by chains of exchanges, which stretched from Cape York to the southern coast of New Guinea, encompassing the Torres Strait islands:

Natives of the islands that lie between Cape York and the coast in that neighbourhood, have a general idea that there are two large countries, one of which they call Mugee Daudthee - New Guinea to the near northward ... [They] have no direct communication with New Guinea, but hear about them and see ornaments, feathers etc. from the country through the Badthoos [Badus] who belong to a group of islands intermediate between the islands on this side of the straits and the

5 The most recent map available to Blackwood and his crew was Flinders' General Chart of Terra Australis or Australia Showing Parts Explored Between 1798 and 1803 (1814), updated in 1822. In this map, the New Guinea coastline has many blanks, while the Torres Strait portion is very detailed.

6 Published as an appendix in Jukes 1847, II: 274-310.

7 Jukes 1847, I: 173. 
natives of another island or islands whom they call the Gamulagagarkadjie ... who, it would appear, communicate immediately with the natives of New Guinea. ${ }^{8}$

Dowdee was inscribed on the map in Figure 7.2. Other place names learned at Erub, such as Keewai (Kiwai), Mowat (Mawata), or Baigoo (Boigu), are easily recognisable as referring to places located either in the contemporary Western Province of Papua New Guinea or in Torres Strait.

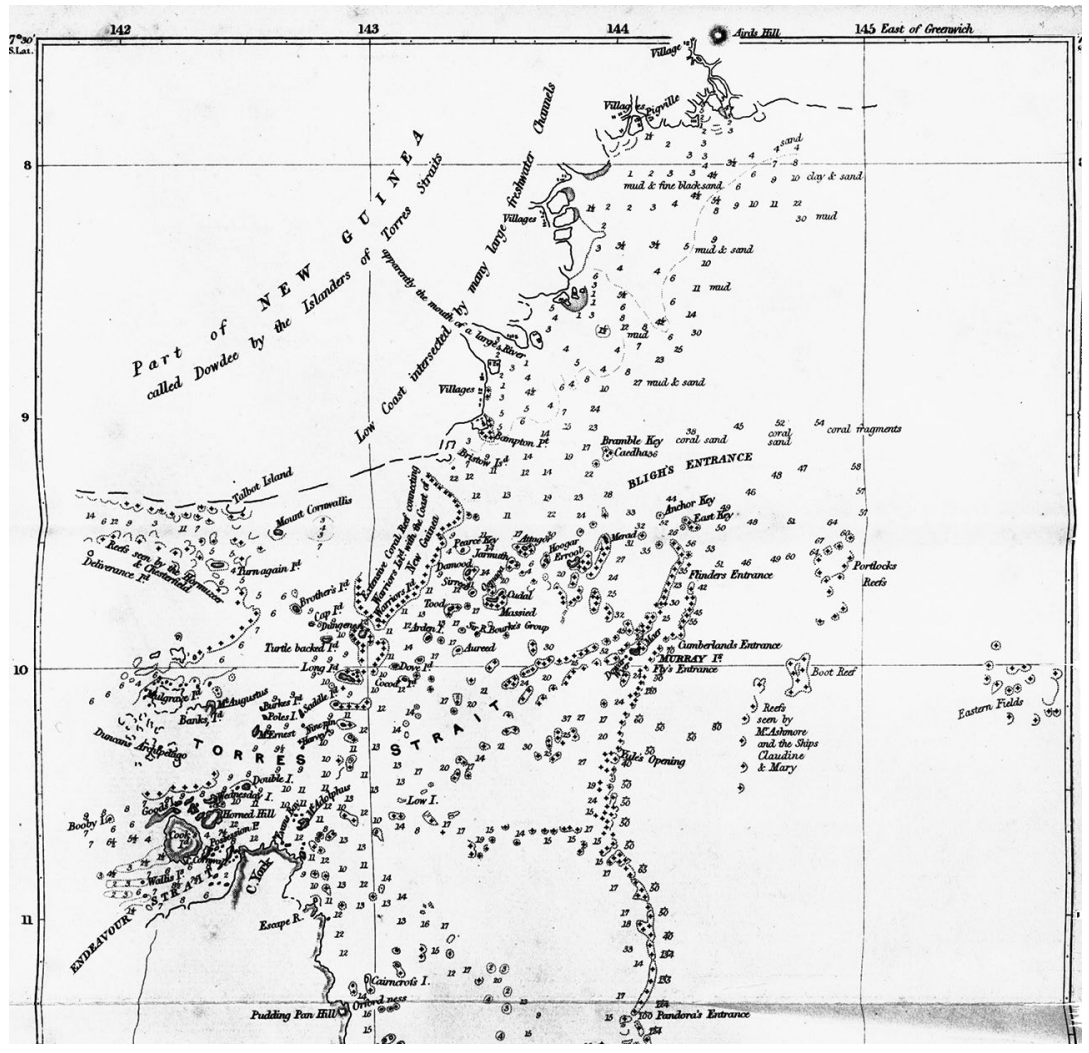

Figure 7.2: Detail of 'Chart of the northern part of the Great Barrier Reef including Torres Strait, \& y. adjacent Coast of New Guinea', 1847.

Source: Joseph Beete Jukes, Narrative of the Surveying Voyage of the H.M.S. Fly, 1847, National Library of Australia. 
The Fly went on to explore the south-west coast of what is now Papua New Guinea and, near what seems to be the mouth of the Fly River, the Europeans' newly acquired linguistic competence enabled peaceful relations centred on exchange. Three canoes came close to the ship: "They approached us very cautiously, and only one came within hail. We then tried them with Eroob words, such as "poud" (peace), "boonarree" (cocoa-nuts), "toorce" (iron), which they appeared to understand. ${ }^{9}$ Other encounters with Indigenous people on this portion of the coast were less friendly and were avoided, '[n]ot wishing to shed blood unnecessarily'. ${ }^{10}$

As the expedition proceeded eastward, Erubian words were increasingly ineffective for communication and this affected European interactions with local people. Due to the navigational difficulties, the pinnace Midge and a gig were sent to survey the coast with provisions for five days, while the Fly continued northward following the coastline. The tender Prince George was meant to stay at signal distance between the two boats. On this occasion, a hill close to the Gulf of Papua, a few miles up the Kikori River, was baptised Aird Hill, giving a more precise position than can be recognised from the maps produced by the expedition. Having received no news from the other boats for some days, the Fly anchored and more boats were sent to find those missing. On 11 May, Blackwood, Jukes, and other members of the expedition explored the shores near Aird Hill in a small boat. Approaching a sandbank, they saw a dozen men armed with bows and arrows: 'We called to them in Erroobian words, which they did not seem to understand, and they shouted words back, which were equally incomprehensible to us. ${ }^{11}$ Apparently frightened at the sight of white men, they fled, but reappeared after some time, keeping themselves at a safe distance. That same day, two other men appeared and one shot an arrow in the direction of the white men who replied with a volley of rifle fire, putting the two to flight. ${ }^{12}$

9 Jukes 1847, I: 213.

10 Jukes 1847 , I: 215 . This is also a rhetorical strategy to morally mask the fear of eventually being killed if a clash occurred; see infra fn. 24 .

11 Jukes 1847, I: 223.

12 For a discussion of the use of firearms in the 'encounters' in the south-eastern part of New Guinea, see Mosko 2009. 
Short of food and concerned about the fate of the missing boats, the party headed back towards the anchored Fly and were suddenly confronted by a large fleet of canoes with several armed men. Blackwood gave 'orders, if it were necessary to fire, to aim at first principally at the canoes, so as to give them some notion what our weapons were capable of, and, if possible, frighten them off without bloodshed' ${ }^{13}$ When some arrows were shot, the muskets were fired without inflicting harm but forced the confronting fleet to flee to gain the shore. Here, in the proximity of a village, the warriors rallied and prepared to attack again, jumping into their canoes. Jukes explained that:

They gradually advanced toward us, and one man seemed inclined to come up alone in a small canoe. We tried him with Erroob words, but he did not seem to understand them, and replied in words unintelligible for us. As we were now so far from the sea, with such a labyrinth of channels to track back, it would evidently never do to proceed with so strong a body of enemies likewise in the rear. ${ }^{14}$

This constituted another failed attempt to use Erubian words to communicate in a potentially dangerous situation. ${ }^{15}$

On 14 May the party rejoined the Fly and the following day met the Prince George, still with no news of the missing boats. At this point, in considerable apprehension for the fate of their companions, Blackwood sent a boat back to Erub in order to collect information. Four days later, the Prince George's crew reported that there was no news of the missing boats. More days passed searching along the coastline but the bad weather, shortage of provisions, and the threat of attacks forced a decision on Blackwood:

as a last chance, Captain Blackwood determined to go to Erroob, and endeavour to persuade one or two of its inhabitants to return with us to New Guinea, in order that by their means we might perhaps procure a peaceful interview with some tribe of the New Guinea people, and thus at least learn what had been the fate of our shipmates. ${ }^{16}$

\footnotetext{
13 Jukes 1847, I: 231.

14 Jukes 1847, I: 233.

15 On the importance of local intermediaries in establishing communications with people encountered during the explorations, see Kennedy 2013: 178-181.

16 Jukes 1847, I: 243.
} 
On 24 May the Fly's crew arrived again in Erub. For three days they tried to persuade Seewai and Mammoos to go with them to New Guinea but the negotiations were complicated by a now open rivalry between the local parties. Analysis of the strategic use of the European presence by the different factions lies outside the scope of this paper, but it is worth noting that the Europeans tried to take advantage of these frictions to serve their goal. Reactions to the request to accompany the Europeans to New Guinea echoed the Torres Strait Islanders' representations of Papuan alterity. Seewai was made aware 'that we wanted him to go with us to talk to the people of Dowdee, that they might inform us where our people were. At this point Seewai shook his head, drew his finger across his throat, and said, "Dowdee no good! arress, aress [war, war]! sarreg [Arrows!]"'. ${ }^{17}$ Exploiting Seewai's enmity with Mammoos to exert pressure, the English temporarily convinced the former to join them but women in the village protested energetically. Later, Mammoos showed scars on his body, some of them the result of fights with Papuans. In the end, Blackwood and his crew could not get any Erubian to go on board; it was clear that ' $[t]$ hey all seemed to regard Dowdee with considerable horror, and said the people of Dowdee would kill them; making signs, by biting their arms, as if they would also eat them afterward' ${ }^{18}$ Tellingly, this is the first mention in the narrative of cannibalism in relation to the inhabitants of New Guinea.

From this point on, the Europeans' attitude to the deployment of firearms in dealing with the inhabitants of the Gulf of Papua changed significantly: 'We were all well armed and the Prince George's sixpounders were cleaned and got in order', as Jukes wrote. ${ }^{19}$ As soon as the expedition approached the Kikori delta, they were confronted by armed men, and 'Captain Blackwood determined to take advantage of the first decided act of hostility on their part, to punish them severely and give them a lesson' ${ }^{20}$ The English also tried to seize prisoners so as to 'acquire some sort of information, or open a communication in a more friendly manner with the rest' ${ }^{21}$ At the first sign of hostility, the cutter crew fired their muskets at a greater rate than expected by Jukes, who justified this course of events by saying, 'The men were just at

17 Jukes 1847, I: 247-248.

18 Jukes 1847, I: 261.

19 Jukes 1847, I: 262.

20 Jukes 1847, I: 264.

21 Jukes 1847, I: 265. 
this time becoming exasperated, with the loss of their messmates in the boats, and expressed great hatred against the blacks' ${ }^{22}$ According to Jukes, 10 to 12 Indigenous men were killed; an extraordinary number if we consider the casualties that might have gone unrecorded..$^{23}$ The next day, the English approached a village and were confronted by a dozen men discharging their arrows at them. Wishing to land, the Europeans decided to clear the zone by firing the six-pounders several times. Here they inspected the long-house, taking some 'ethnological specimens' and killing two pigs.

In sarcastic remorse for this act of theft, Jukes wrote: 'I will so far endeavour to make amends to the inhabitants of Pigville, as we christened this place, as to acknowledge that their pork was excellent. ${ }^{24}$ It is worth noting that the objects 'collected' were compared with the Erubians' material culture, and on a subsequent visit to Erub the Europeans relied on that knowledge to make sense of some objects:

a cane loop, with a toggle or handle, and a bamboo scoop, with a handle bound round with twine, in which small beads (or seeds) were inserted. I afterwards saw some of these among the natives at Erroob, who said they came from Dowdee ... and said the first was for twisting round people's necks, and the second for cutting their heads off - which merely showed they did not know what their real use was, as they are not at all adapted for those purposes. ${ }^{25}$

22 Jukes 1847, I: 265, note. The crew subsequently learned that the missing men had gone in the Midge to the English settlement at Port Essington in Arnhem Land. Jukes 1847, I: 302.

23 Bronwen Douglas (pers. comm.) suggests that the number of killings listed in such encounters was often much exaggerated, on the basis of the assumed superiority of European arms. This interpretation is sustained by the convincing argument developed by Dorothy Shineberg (1971) that firearms proved ineffective in the early phase of European exploration of the Pacific, a position that resonates with Kennedy's: 'The technological hubris that inspired many expeditions collided with the constraints of climate, topographies, political economies, and more' (Kennedy 2013: 262). I have argued elsewhere (Di Rosa 2010: 66, chapter 2) that, in the late nineteenth-century exploration of the Gulf of Papua, firearms were often thought of and deployed as a tangible symbol of Europeans' supposed superiority. Even if firearms did not prove effective in the humid climate of the Gulf of Papua, it was through these objects that Europeans could hold a sense of confidence to sustain them during the exploration of unknown lands and waters, and the potentially hazardous encounters with the inhabitants of those territories.

24 Jukes 1847, I: 276.

25 Jukes 1847, I: 277-278. 
Michael O'Hanlon has discussed at length the implications of the socalled 'man-catcher' in southern Papua New Guinea, showing the various complex forms of representations that such objects provoked in various sectors of the European colonial community in what was then the Protectorate of British New Guinea. ${ }^{26}$

This is an example of how Erubians associated New Guinea with headhunting practices. Other encounters also took place in New Guinea, mostly marked by tensions, but I want particularly to emphasise the constant English attempt to use Erubian words in order to establish communications there. It is interesting that Jukes thought he could recognise some words from the vocabulary collected in the Torres Strait, segmenting the continuum of the sound-string they were hearing to accord with his expectations. For example, on 29 May, the Fly's crew encountered some men and Jukes described the event:

When they were within about 100 yards, Captain Blackwood and myself stood up on the taffrail and waved our hats, shouted 'puod, poud,' and told them in Erroob we were friends, and invited them to come to us. They ceased their cries and listened; and I thought once I heard them say to each other, 'Errooba. ${ }^{27}$

On another occasion:

We again tried them with Erroob words, and, I think, they understood 'toorree' (iron), and answered to us, 'nipa' (a knife). We held up hatchets, and again said 'toorree', when they, I believe, repeated 'nipa,' and seemed to apply the word to the hatchet, as if it were a foreign word they had heard, but did not know the exact meaning of. They certainly never used the word 'sapăra,' which is the Erroobian word for hatchet. ${ }^{28}$

These are further traces of how sustained engagement with some parts of the Torres Strait Islands informed tentative European interactions with people of the Gulf of Papua. 
BROKERS AND BOUNDARIES

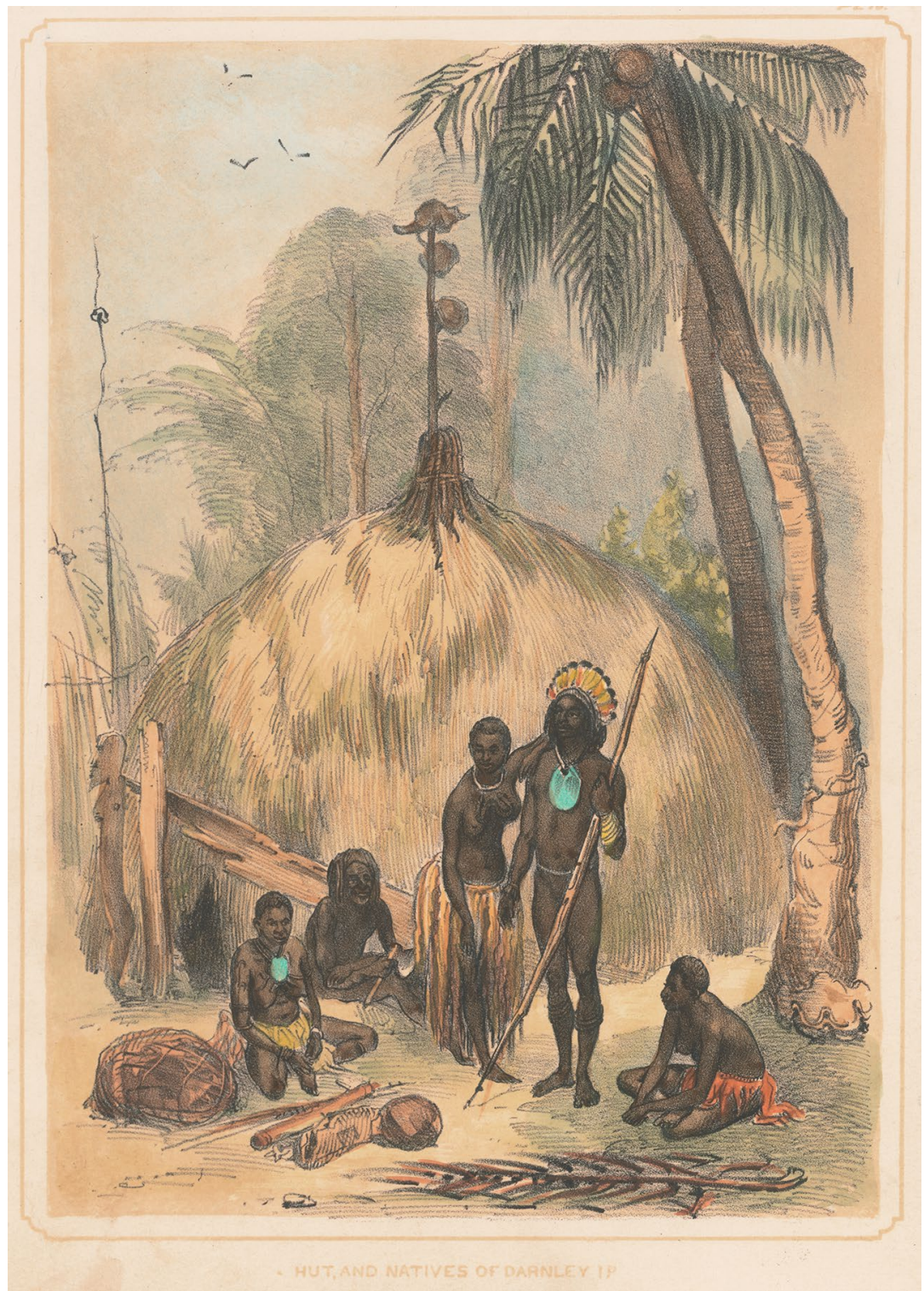

Figure 7.3: H. S. Melville, 'Hut, and Natives of Darnley Id. [Island]', n.d.

Source: H. S. Melville, Sketches in Australia \& the Adjacent Islands, n.d. [1849?], Plate 18, National Library of Australia. 
Although Erubians did not physically accompany Blackwood and his crew to the Papuan coast, they mediated subsequent encounters with Papuans in two ways. They provided a vocabulary that enabled easier engagement in exchanges, thus establishing peaceful encounters. When linguistic communication, no matter how 'raw', failed, the potential for clashes with the Indigenous people encountered became a real threat, as has already been seen. Previous interactions with Indigenous people provided cognitive and behavioural tools to tame the unknown nature of the encounters. When these cognitive resources proved ineffectual, thus failing to 'establish friendly relations', the actions of the Europeans were guided by more familiar stereotypes of 'the Native', which enabled moral justification for the recourse to violence. This brings me to my second point, that sustained engagement with Erubians mediated the European imaginary of the alterity of the inhabitants of the Gulf of Papua. The dialogical construction of Papuan alterity, reified in a gruesome way in the encounters described above, significantly shifted the Europeans' rhetoric and course of actions from 'not shedding unnecessary blood' to 'teaching them a lesson' ${ }^{29}$

Archaeological, historical and ethnographic evidence shows that Torres Strait Islanders and Papuans of the south coast of New Guinea were entangled in exchange practices, intermarriage, and also raids. ${ }^{30}$ Signs of these relationships were in place when Blackwood and his crew arrived in the region. For example, the presence of a New Guinea woman on Darnley Island was recorded by the draughtsman Harden Sidney Melville in one of his sketches entitled 'Hut, and Natives of Darnley Id [Island]': 'Sitting on the left is a New Guinea woman the cause of whose presence on Darnley Island we could not ascertain' (Figure 7.3). ${ }^{31}$ Again, Jukes observed that Torres Strait Islanders greatly esteemed the cuscus, which came from the southern New Guinea coast, as did the canoes in use in the Strait. It was from interactions with specific groups on the Papuan coast that Torres Strait Islanders formed images of their alterity, taken by Europeans as applicable to the whole country. Goods generated from the exchanges taking place between

29 On the ambiguous relation between violence and ethics during the geographical explorations, see Driver and Jones 2009: 46-47; Kennedy 2013: 204-221. For a discussion of the moral dimension of the deployment of violence in exploring the Kikori area in the Gulf of Papua between the nineteenth and twentieth centuries, see also Di Rosa 2010. For a fruitful analysis of the intersection of morality, violence, and distance see Ginzburg 1994.

30 See, for example, Austen 1948; Allen 1982; McNiven 1998.

31 Melville [1849]: plate 18. 
the Torres Strait Islanders and the Papuans of the opposite coast made their way to the Kikori River, and from there were integrated into other exchange routes that stretched as far as the Highlands. ${ }^{32}$ These objects, though, travelled by means of personal trading relations, along a sequence of societies with their constellations of enmities and alliances. A long dialect chain of languages is to be found in this part of the Gulf of Papua (Figure 7.4), which rendered unnecessary the development of a common language. Instead, for example, the Motuan language became the lingua franca of the hiri trade in the eastern part of the Gulf. ${ }^{33}$ This enables a more detailed understanding of the complex geopolitics that informed Indigenous constructions of alterity, which in turn impinged on European understandings and engagements with people encountered during the process of exploration. These complex local worlds were often flattened under the category of 'natives'.

As I observed at the beginning of this chapter, Jukes's narrative became a canonical text for later explorations of the Gulf of Papua, becoming itself a mediator of the European imaginary of the Gulf. For example, in 1890 the Lieutenant Governor of the then British New Guinea, William MacGregor, located as Pigville the place where 'during my recent inspection of the western district we were ... completely unsuccessful in our endeavours to establish friendly relations with natives'. ${ }^{34}$ But Jukes's legacy runs even further: the anthropologist Alfred Cort Haddon was an eager reader of the Fly narrative, and praised the expedition's ethnographic work in Torres Strait in his multi-volume Report of the Cambridge Anthropological Expedition. ${ }^{35}$ Close reading of this text enabled him, years later while he was working in the Gulf, to locate Pigville as a Kerewo village in the Kikori Delta. ${ }^{36}$ It is not of primary importance for me to be able to locate this village exactly, but rather to see how Jukes's narrative, the outcome of the complex kaleidoscopic refractions of representations, operated as a blueprint for understanding encounters in the Gulf of Papua almost 60 years later.

32 See Austen 1948: 16-20.

33 The hiri trade was an annual voyage undertaken by Motu people, sailing toward the Gulf of Papua in order to exchange mostly clay pots for sago. The so-called Hiri Motu language developed from such interactions; see Dutton 1982.

34 MacGregor 1892: 54.

35 Haddon 1901-35.

36 Haddon 1918: 179. 


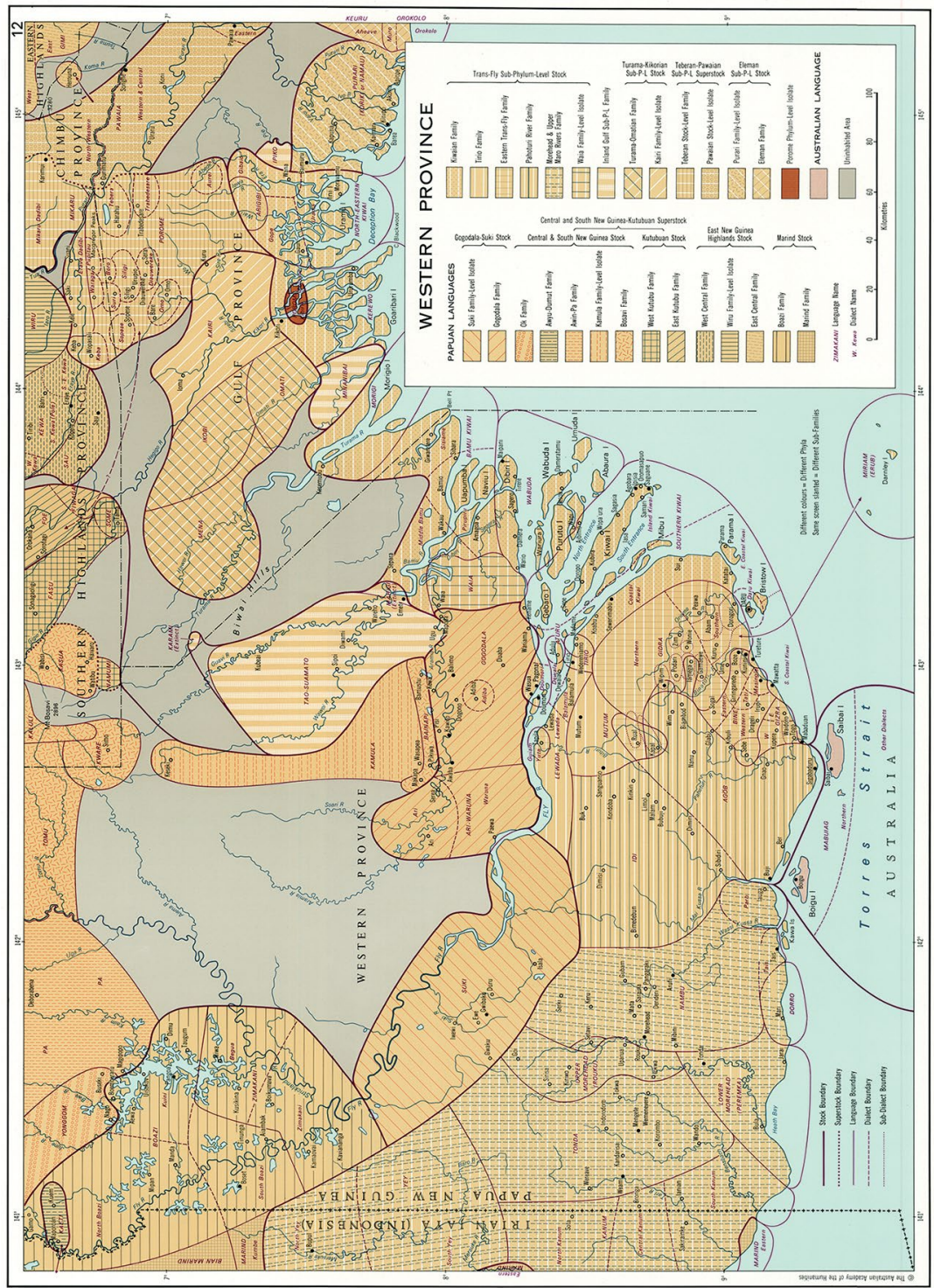

Figure 7.4: Map of languages in Gulf of Papua area, 1981.

Source: C.L. Voorhoeve and Stephen A. Wurm, 'Western Province', in Stephen A. Wurm and Shirô Hattori (eds), Language Atlas of the Pacific Area, 1981, Australian Academy of the Humanities; reproduced with permission.

The case analysed in this chapter is not uncommon in Pacific exploration literature and arguably in that of exploration generally. For example, in a narrative of his voyage along the south coast of New Guinea with 
Luis Váez de Torres in 1606, Diego de Prado y Tovar recounted that the indios ('Indians') of Mailu Island fled at the sight of an African member of the Spanish crew, terrified because he resembled negros ('Negroes') who raided them and ate the bodies of their victims. When the Spanish landed on an island in what would become known as Torres Strait and saw skulls in the huts, they assumed that these must be the people the inhabitants of Mailu were frightened of, though they were 'not black', 'but stain themselves to appear more fierce'. ${ }^{37}$

Reading these narratives of encounters with Indigenous people is a reminder of the significance of imagination in shaping the expectations which guided the actions of Europeans toward the people and places they met, readjusting their understanding, and consequently their behaviour, according to whether those expectations were met or not. This imaginary was partly formed by interactions with local communities, adhering in the process to 'local' stereotypes which were readily and uncritically naturalised. These revised expectations entered the published accounts consulted by subsequent explorers prior to their own voyages. I am not arguing for a mere analysis of the 'construction of the imaginary' that leads to a mechanistic reading of parties' actions. The imaginary influenced the actions and interactions of Europeans and Indigenous people, whose own imaginary was no less important in their encounters with the white newcomers. For example, in several passages Jukes noted local attitudes toward the white skin and other material signs of European alterity, such as the footprints they left on the ground: 'They seemed to be pointing with great surprise to our foot-marks, wondering no doubt what had become of our toes, and at the extraordinary shaped feet they must have concluded we had from the impressions of our shoes. ${ }^{.38}$

In his unpublished journal of the voyage of HMS Bramble, ${ }^{39} \mathrm{John}$ Sweatman compared the encounters of Blackwood and his crew in the Kikori delta with those they had at Cape Possession, further east

\footnotetext{
37 Prado y Tovar 1930: 160.

38 Jukes 1847, I: 278.

39 John Sweatman was a clerk on HMS Fly during the voyage discussed in this chapter and then joined HMS Bramble, which conducted explorations in the South Sea after the Fly set sail for England. The Bramble visited the southern portion of New Guinea in 1846. Sweatman's journal remained unpublished until the 1970s and, as far as is known, only the second volume survives (Sweatman, Journal, n.d., SLNSW MS A1725). We are thus deprived of a different perspective on the Fly's voyage. For a historical contextualisation of this manuscript, see Sweatman 1977.
} 
in the Gulf of Papua. He noted that the people they met were not frightened by their white skin. Sweatman linked this observation to the overall better Indigenous disposition toward the Europeans at Cape Possession, venturing to say that they 'were willing to be as familiar as the Darnley Islanders', ${ }^{40}$ who, once again served as the 'yardstick of encounters'. The study of how certain Europeans' imaginaries were formed, both 'at home' and during the temporal frame of the voyages, leads the historian to look at broader questions about the political environment in which Europeans moved. However, this should not diminish the significance of the time-situated actions that these imaginaries reify. Such actions can be partially recovered in the texts, inscribed as Indigenous countersigns. ${ }^{41}$

Stating the relevance of the imagination in shaping knowledge created during the explorations of 'unknown' territories is a scholarly truism. In his work on the British Ornithologists' Union expedition to the interior of what was then Dutch New Guinea, Chris Ballard elegantly reconstructs the history of the 'Pygmy mythology', and the relevance that travel literature pertaining to Central Africa had for understanding the encounters with some human groups in the interior of New Guinea. The nexus between the imagination and its reification during the encounter is well captured by the following quote:

The discovery of Negritos or Pygmies in the forested highland interior of New Guinea was thus keenly anticipated, and the characteristics of these imagined communities mapped in detail and commonly understood well in advance of the actual encounter. ${ }^{42}$

The case study I examined in this chapter shows that, at least in some cases, Indigenous stereotypes of neighbouring tribes infiltrated into the European's pre-constituted categories of 'the Natives' - something that is often neglected. It would be an exaggeration to attribute the

\footnotetext{
40 Sweatman n.d., NLA Mfm G 27522: 188.

41 For an outline of the fruitful methodology she developed to recover signs and countersigns of Indigenous agency inscribed in written texts, see Douglas 2015; 2014: 18-26.

42 Ballard 2000: 135.
} 
course of events solely to the interactions ${ }^{43}$ between the British crew and the Erubians, as the actual physical encounter with people in the Gulf of Papua was no less real and dangerous regardless of the cognitive tools that shaped the post facto understanding of it. The magmatic interaction between European and Indigenous imaginations with the uncertainties opened in the space of the encounter, crystallises in texts; in this case Jukes's, which, as I already argued, became a mediator of the imaginary of later explorations of the Gulf of Papua. It was no accident that the naturalist's text became authoritative in a period of transition from fictional accounts to travel literature to scientific reports of geographical explorations. Jukes stated his 'regime of truth' in the Preface to the volume in the following terms:

in works of this nature, one line of plain facts is better than any heightened recollection ... For this reason, also, I have avoided all attempts of brilliancy, elegance, or graces of style, and endeavoured to relate with simplicity and fidelity whatever I had to tell, either of personal adventure, or of scientific research. ${ }^{44}$

For the subsequent colonial endeavour to understand and tame New Guinea, 'scientific accuracy' was deemed to be absolutely crucial.

\section{Acknowledgements}

I thank the organisers and participants of the 'Local Intermediaries in International Exploration' conference at The Australian National University in July 2013 for their fruitful comments. I particularly acknowledge Chris Ballard, Bronwen Douglas and Graeme Whimp for their warm support and thoughtful suggestions.

43 Tamisari distinguishes between 'meeting' and 'encounter' on the basis of the intensity and personal involvement of relationship that take place during the ethnographic fieldwork experience, shaping the knowledge produced by the ethnographer. Tamisari's distinction is worth further reflections by historians whose interest revolves around 'intercultural encounters', but this cannot be done in the space of a footnote. What I want to stress here is that the quality of relations between the Fly's crew and some Erubian people opened for the permeation of Europeans' imaginary by local stereotypes of inhabitants of 'Dowdee' (Tamisari 2006).

44 Jukes 1847; I: vi; my emphasis. Ballard (2009) convincingly demonstrates that certain literary tropes developed in fictional travel accounts were 'at work' in later texts of a scientific nature. Jukes's regime of truth is echoed by Melville [1849] in his Preface: 'In submitting this little work to the public, I have been actuated by the wish to lay before them facts rather than fancies. As an artist I am well aware of the small merit they posses as pictures, and wish to rest their value solely on their being faithful representations of the objects seen.' 


\section{References}

Allen, Jim 1982, 'Pre-contact trade in Papua New Guinea', in Melanesia: Beyond Diversity, Ronald J. May and Hank Nelson (eds), Research School of Pacific Studies, The Australian National University, Canberra, 193-206.

Austen, Leo 1948, 'Notes on the Turamarubi of Western Papua', Mankind 4: 14-23.

Ballard, Chris 2000, 'Collecting Pygmies: The "Tapiro" and the British Ornithologists's Union Expedition to Dutch New Guinea, 19101911', in Hunting the Gatherers: Ethnographic Collector, Agents, and Agency in Melanesia, 1870s-1930s, Michael O'Hanlon and Robert L. Welsch (eds), Berghahn Books, New York and Oxford, 127-154.

2009, 'The art of encounter: Verisimilitude in the imaginary exploration of interior New Guinea, 1725-1876', in Oceanic Encounters: Exchange, Desire, Violence, Margaret Jolly, Serge Tcherkézoff and Darrell Tryon (eds), ANU E Press, Canberra, 221-257.

Beer, Gillian 1996, Open Fields: Science in Cultural Encounters, Calderon Press, Oxford.

Dening, Greg 1992, Mr Bligh's Bad Language: Passion, Power, and Theatre on the Bounty, Cambridge University Press, Cambridge and New York.

Di Rosa, Dario 2010, 'Il caso Goaribari: violenza e saperi nella Papua coloniale', MA thesis, Ca'Foscari University of Venice.

Douglas, Bronwen 2014, Science, Voyages, and Encounters in Oceania 1511-1850, Palgrave Macmillan, Basingstoke and New York.

2015, Agency, affect, and local knowledge in the exploration of Oceania', Indigenous Intermediaries: New Perspectives on Exploration Archives, Shino Konishi, Maria Nugent and Tiffany Shellam (eds), ANU Press, Canberra, 103-130.

Driver, Felix and Lowri Jones 2009, Hidden Histories of Exploration: Researching the RGS-IBG Collections, Royal Holloway, University of London, and Royal Geographical Society (with IBG), London. 
Dutton, Tom (ed.) 1982, The Hiri in History: Further Aspects of LongDistance Motu Trade in Central Papua, Pacific Research Monograph 8, The Australian National University, Canberra.

Fabian, Johannes 2000, Out of Our Minds: Reason and Madness in the Exploration of Central Africa, University of California Press, Berkeley, Los Angeles, London.

Flinders, Matthew 1814, 'General chart of Terra Australis or Australia: Showing the parts explored between 1798 and 1803', engraving, in A Voyage to Terra Australis: Undertaken for the Purpose of Completing the Discovery of that Vast Country, and Prosecuted in the Years 1801, 1802, and 1803 in His Majesty's Ship the Investigator, and Subsequently in the Armed Vessel Porpoise and Cumberland Schooner ... Atlas, plate 1, G. and W. Nicol, London.

1822, 'General chart of Terra Australis or Australia: showing the parts explored between 1798 and 1803 by M. Flinders Commr. of H.M.S. Investigator', Admiralty Hydrographical Office, London.

Ginzburg, Carlo 1994, 'Killing a Chinese mandarin: The moral implications of distance', Critical Inquiry 21: 46-60.

Haddon, Alfred Cort (ed.) 1901-1935, Reports of the Cambridge Anthropological Expedition to Torres Straits, 6 vols, Cambridge University Press, Cambridge.

_ 1918, 'The Agiba cult of the Kerewa culture', Man 18: 117-183.

Herzfeld, Michael 2005 [1997], Cultural Intimacy: Social Poetics in the Nation-State, second edition, Routledge, London and New York.

Jukes, J. Beete 1847, Narrative of the Surveying Voyage of H.M.S. Fly, Commanded by Captain Blackwood, in Torres Strait, New Guinea, and Other Islands of the Eastern Archipelago, during the Years 18421846: together with an Excursion into the Interior of the Eastern Part of Java, 2 vols, T. \& W. Boone, London.

Kennedy, Dane K. 2013, The Last Blank Spaces: Exploring Africa and Australia, Harvard University Press, Cambridge and London. 
MacGregor, William 1892, 'Despatch Reporting Further Upon Administrative Visit of Inspection to Western Division', in Annual Report on British New Guinea 1890-1891, Appendix M (27 April 1891), Government Printer, Brisbane, Qld, 46-54.

McNiven, Ian J. 1998, 'Enmity and amity: Reconsidering stoneheaded club (gabagaba) procurement and trade in Torres Strait', Oceania 69: 94-115.

Melville, Harden S. [1849], Sketches in Australia and the Adjacent Islands: Selected from a Number Taken during the Surveying Voyage of HMS "Fly" and "Bramble" under the Command of Capt. FP Blackwood ... 1442-1846, Dickinson \& Co., London.

Moore, David R. 1979, Islanders and Aborigines at Cape York: An Ethnographic Reconstruction Based on the 1848-1850 "Rattlesnake" Journals of O.W. Brierly and Information he Obtained from Barbara Thompson, Australian Institute of Aboriginal Studies, Canberra.

Mosko, Mark S. 2009 'Black powder, white magic: European armaments and sorcery in early Mekeo and Roro encounters', in Oceanic Encounters: Exchange, Desire, Violence, Margaret Jolly, Serge Tcherkézoff and Darrell Tryon (eds), ANU E Press, Canberra, 259-293.

O'Hanlon, Michael 1999, "Mostly harmless"? Missionaries, administrators and material culture on the coast of British New Guinea', Journal of the Royal Anthropological Institute 5: 377-397.

Prado y Tovar, Diego de 1930, 'Relación Sumaria de Don Diego de Prado with an annotated translation', in New Light on the Discovery of Australia: As Revealed by the Journal of Captain Don Diego de Prado y Tovar, George F. Barwick (trans.), Henry N. Stevens (ed.), Hakluyt Society, London, 83-205.

Schieffelin, Edward L. and Robert Crittenden (eds) 1991, Like People You See in a Dream: First Contact in Six Papuan Societies, Stanford University Press, Stanford.

Shineberg, Dorothy 1971, 'Guns and men in Melanesia', Journal of Pacific History 6: 61-82. 
Sweatman, John n.d., 'Journal of a surveying voyage in the "Bramble", 1842-1847', State Library of New South Wales, MS A1725; National Library of Australia, microfilm Mfm G 27522.

1977, The Journal of John Sweatman: A Nineteenth Century Surveying Voyage in North Australia and Torres Strait, Jim Allen and Peter Corris (eds), University of Queensland Press, St Lucia.

Tamisari, Franca 2006, 'Personal acquaintance: Essential individuality and the possibilities of encounters', in Moving Anthropology: Critical Indigenous Studies, Tess Lea, Emma Kowal and Gillian Cowlinshaw (eds), Charles Darwin University Press, Darwin, 17-36.

Thomas, Nicholas 1994, Colonialism's Culture: Anthropology, Travel and Government, Princeton University Press, Princeton.

Thomas, Nicolas 2010, Islanders: The Pacific in the age of empire, Yale University Press, New Haven.

Wurm, Stephen A. and Shirô Hattori (eds) 1981, Language Atlas of the Pacific Area. Part 1: New Guinea area, Oceania, Australia, Pacific Linguistics. Series C, No. 66, Australian Academy of the Humanities [and] the Japan Academy, Canberra. 
This text is taken from Brokers and Boundaries: Colonial Exploration in Indigenous Territory, edited by Tiffany Shellam, Maria Nugent, Shino Konishi and Allison Cadzow, published 2016 by ANU Press, The Australian National University, Canberra, Australia. 